\title{
Epidemiologic pattern of patients with neurocysticercosis diagnosed by computed tomography in Curitiba, Brazil
}

\author{
Ana Laura Grazziotin', Mariana Campos Fontalvo², \\ Marilis Beckert Feijó Santos², Fernanda Monego', Ana Line Grazziotin², \\ Victor Hugo Zanini Kolinski ${ }^{2}$, Rodrigo Henrique Bordignon², \\ Alexander Welker Biondo ${ }^{3}$, Affonso Antoniuk ${ }^{4}$
}

\begin{abstract}
The aim of this study was to drawn an epidemiological pattern of neurocystisticercosis (NCC) patients diagnosed by computed tomography at the major private diagnostic center in Curitiba, Brazil. A total of 1,009 medical files of consecutive patients presenting neurological indications were diagnosed by computed tomography from July 2007 to April 2008. Patient data included sex, age, municipality and tomography findings were analysed by Epi-info version 6.0.1. software. Most patients (81.10\%) were living in Curitiba. A total of 91/1,009 cases (9.02\%) were considered positive to NCC; 88 (96.7\%) patients had inactive form of NCC and only $3(3.2 \%)$ patients had cysts in granulomatous process. No patients had both forms. The prevalence of NCC cases in studied group was greater in patients between 51 to 60 years old, however, difference between sex was not significant. This epidemiological pattern of NCC was similar to the first NCC study in Curitiba, performed in $1995-1996$ with $9.24 \%$ of positive cases.
\end{abstract}

Key words: neurocysticercosis, cysticercus cellulosae, epidemiology.

Perfil epidemiológico de pacientes com neurocisticercose diagnosticados por tomografia computadorizada em Curitiba, Brazil

\section{RESUMO}

Determinou-se o perfil epidemiológico da neurocisticercose (NCC) em pacientes diagnosticados por tomografia computadorizada (TC) no maior centro privado de diagnósticos de Curitiba, Brasil. Foram analisados 1009 registros médicos de pacientes consecutivos com indicações neurológicas submetidos a TC entre julho de 2007 a abril de 2008. Os dados dos pacientes que incluíram sexo, idade, município de residência e

\section{Correspondence}

Alexander Welker Biondo

Departamento de Medicina Veterinária Setor de Ciências Agrárias, Campus Agrárias Rua dos Funcionários 1540 80035-050 - Curitiba PR - Brasil E-mail: abiondo@illinois.edu

\section{Financial support}

Dr. Grazziotin was sponsored by a fellowship from Fundação Araucária for her Masters of Science in the College of Cellular and Molecular Biology at the Federal University of Paraná

Received 26 August 2009

Received in final form 24 November 2009 Accepted 4 December 2009 achados tomográficos foram analisados pelo software Epi-info versão 6.01. A maioria dos pacientes $(80,10 \%)$ era procedente de Curitiba; $91 / 1.009$ casos $(9,02 \%)$ foram positivos para NCC; $88(96,7 \%)$ apresentaram a forma inativa e apenas em $3(3,2 \%)$ cistos em processo granulomatoso; não houve formas mistas. A prevalência de casos de NCC foi maior entre 51 e 60 anos. Não houve diferença significativa para o sexo entre os casos. O perfil dos pacientes diagnosticados para NCC por TC neste estudo é semelhante ao estudo anterior realizado em Curitiba entre 1995-1996, com 9,24\% de casos de NCC.

Palavras-chave: neurocisticercose, cysticercus cellulosae, epidemiologia.

'DVM, graduate student, Graduate College of Cellular and Molecular Biology, Federal University of Paraná, Curitiba PR, Brazil; ${ }^{2} \mathrm{DVM}$, College of Veterinary Medicine, Federal University of Paraná, Curitiba PR, Brazil; ${ }^{3} \mathrm{DVM}, \mathrm{MSc}$, PhD, Assistant Professor, Department of Veterinary Medicine, Federal University of Paraná, Curitiba PR, Brazil, and visiting Professor at The University of Illinois, Urbana-Champaign, IL, USA; ${ }^{4}$ MD, Msc, PhD, Professor of Neurosurgery, Department of Neurosurgery, Federal University of Paraná, Head of Advanced Image Diagnostic Center - DAPI, Curitiba PR, Brazil. 
Neurocysticercosis (NCC) is a worldwide spread zoonosis caused by Cysticercus cellulosae, a larval stage of Taenia solium. The disease is considered one of the most important infections of central nervous system and a severe neglected health problem, particularly in developing countries ${ }^{1}$. According to Pan American Health Organization approximately 50 million people worldwide are infected and overall mortality is around 50 thousand people a year ${ }^{1}$. Neurocysticercosis has been reported in most Brazilian states, with higher prevalence in Paraná, São Paulo, Minas Gerais, and Goiás ${ }^{2}$. Costs due to NCC treatment and complications in Brazil may reach up to U\$ 85 million $^{3}$. NCC has traditionally been a parasitic disease of rural settings, related to poor personal hygiene habits and sanitary structure conditions ${ }^{4}$. In contrast, neurocysticercosis has been more recently recognized in urban areas, even when basic sanitation facilities are provided ${ }^{2,5-8}$.

Curitiba is the capital of Parana state and currently the seventh most populated capital in Brazil, with 1,828,092 habitants within city and a metropolitan area of 26 cities and 3,172,357 people 9 . Study on NCC prevalence of patients diagnosed by computed tomography (CT) was conducted in Curitiba in 1995 and 1996, with 9,24\% ${ }^{6}$.

In this study we evaluate the frequency and epidemiologic pattern of neurocysticercosis in patients from the Advanced Image Diagnostic Center, the major private center of Curitiba, Southern Brazil.

\section{METHOD}

A descriptive study was conducted at the Advanced Image Diagnostic Center (AIDC), located in Curitiba, Parana state capital, Brazil, based on 1009 individual medical files of consecutive patients from July 2007 to April 2008 diagnosed by CT (axial sections ranged 10 $\mathrm{mm}$ ). Patients attended at the AIDC were from different cities of Parana State and outside states, and includ-

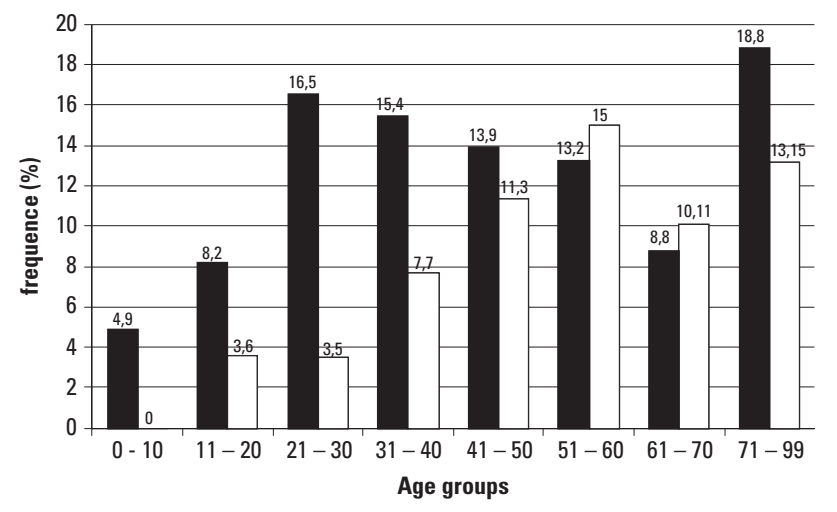

$\%$ of age group $\square \%$ of NCC

Fig 1. Distribution (\%) of patients in age groups: total group, 1009 patients and NCC group 91 patients. ed patients with public, private or no health insurance. Suggestive cases were obtained by image of pathological manifestations compatible with NCC, such as calcification areas with no capture of contrast, calcifications with granulomatous process regarding to parasitic lesion resolution and viable cysts of variable sizes with little or absence capture of contrast.

Data from individual medical file included sex, age, municipality (place of residence), pathologies associated to NCC, exam date, appearance and localization of viable or calcified cysts were used for the analysis. Statistical analysis was used to evaluate the prevalence (p) and odds ratio (Odds) through the Epi-Info software version 6.0.1 with 95\% confidence interval. Data were considered significant when $\mathrm{p}<0.05$.

\section{RESULTS}

A total of 1,009 medical reports about cranial CT were analyzed during the study period, from which 91 (9.02\%) were considered suggestive of NCC based on pathological manifestation presented on the imaging report. Out of the 91 NCC suggestive cases, 88 (96.7\%) presented calcified cysts and three showed hypodense cysts in process of granuloma development. However, there is no patient presenting both forms of NCC. Measurements were described only in five cases: three calcifications with 2, 3 and $6 \mathrm{~mm}$ of diameter, and two hypodense cysts with 8 $\mathrm{mm}$ and $10 \mathrm{~mm}$ of diameter. Calcifications were found in the parietal, frontal, occipital and temporal lobes, as well as in the basal ganglia.

Regarding sex, 9.4\% (64/677) cases were female NCC suggestive, whereas $8.1 \%$ (27/332) were male. Based on statistical analysis, sex is not considered a risk factor for the present study (p 0.49 Odds 1.18 CI 0.72-1.94). The age groups of NCC patients varied from 16 to 90 years, with an average of 55.15 years and mostly patients between

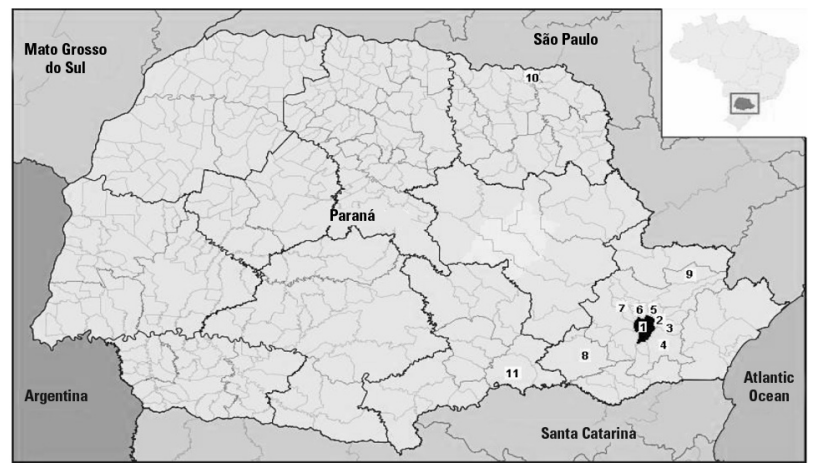

Fig 2. Municipalities with NCC suggestive cases. Municipalities: [1] Curitiba; [2] Pinhais; [3] Piraquara; [4] São José dos Pinhais; [5] Colombo; [6] Almirante Tamandaré; [7] Campo Largo; [8] Lapa; [9] Tunas do Paraná; [10] Andirá e [11] São Mateus do Sul. 
Table. Distribution of patients attended in the Advanced Image Diagnostic Center by residence municipality. Comparison of NCC suggestive cases and NCC negative cases by region.

\begin{tabular}{lcccc}
\hline Municipality & $\begin{array}{c}\text { Total of } \\
\text { attendances }\end{array}$ & $\begin{array}{c}\text { NCC } \\
\text { negative }\end{array}$ & $\begin{array}{c}\text { NCC } \\
\text { suggestive }\end{array}$ & $\begin{array}{c}\text { NCC } \\
\%\end{array}$ \\
\hline 1. Almirante Tamandaré & 20 & 17 & 3 & 15.0 \\
2. Andirá & 1 & 0 & 1 & 100 \\
3. Campo Largo & 12 & 9 & 3 & 25.0 \\
4. Colombo & 16 & 12 & 4 & 25.0 \\
5. Curitiba & 818 & 747 & 71 & 8.7 \\
6. Lapa & 3 & 1 & 2 & 66.7 \\
7. Pinhais & 12 & 11 & 1 & 8.3 \\
8. Piraquara & 10 & 8 & 2 & 20.0 \\
9. São José dos Pinhais & 30 & 29 & 1 & 3.3 \\
10. São Mateus do Sul & 1 & 0 & 1 & 100 \\
11. Tunas do Paraná & 1 & 0 & 1 & 100 \\
Non identified & 1 & 0 & 1 & 100 \\
Total to Paraná State & 925 & 834 & 91 & 9.8 \\
Total to other States & 84 & 84 & 0 & 0 \\
Total to all States & 1009 & 918 & 91 & 9.0 \\
\hline
\end{tabular}

51 to 60 years of age (Fig 1 ). The prevalence of NCC cases was greater continuously with age (p 0.044 Odds 4.72 CI 1.27-20.70).

Municipalities with suggestive cases of NCC are shown in Figure 2. Table shows the geographic distribution of the NCC suggestive patients' city of residence in relation to the total of patients attended in the same municipality. A total of 818/1,009 (81.10\%) patients were residents of Curitiba, with higher NCC suggestive cases as well with $71 / 818$ cases $(78.02 \%)$, followed by surrounding cities of metropolitan area.

\section{DISCUSSION}

The first report of NCC from patients with neurologic indications in Curitiba analyzed 3,090 consecutive tomographies from 2,554 patients, showed an overall 9.24\% prevalence in $1996^{6}$. The present study found $9.02 \%$ prevalence into 1,009 consecutive patients with neurological signs, similar to the previous study. However, the frequency found was higher when compared to another study in Parana State (0.78\% in Maringa) ${ }^{7}$.

Although prevalence in neurological patients has not significantly changed in the past 15 years in Curitiba, studies based on autopsy findings have showed that Parana state has the highest frequency (4.8\%) of NCC cases among general hospitals of Brazilian states ${ }^{2}$. An overall of 4,040 human cases of cysticercosis were notified in the Parana state from 1980 to $2000^{10}$. In studies using computed tomographies in other regions of Brazil the prevalence was $0.19 \%$ in Baixada Fluminense - Rio de Janeiro ${ }^{5}$,
1.02\% in Campina Grande - Paraíba ${ }^{11}$ and $1.27 \%$ in Santa Maria - Rio Grande do Sul ${ }^{12}$.

Female has been the most predominant for the NCC suggestive cases ${ }^{5-8,12,13}$. We found 70.3\% (64/91) women and 29.6\% (27/91) men among NCC patients, indeed represent 9.4\% (64/677) and 8.1\% (27/332) among entire female and male studied population, respectively. Therefore, in this study this data can be justified by a higher search rate for diagnosis procedures among females (approximately 1 man: 2 women). Based on statistical anal$y$ sis ( $p>0.05$ ), sex was not considered a risk factor for the present study.

NCC in Brazil has been shown to be more prevalent in patients among 21 to 60 years ${ }^{2}$. The prevalence of NCC in studied group was greater in patients over 41 years of age, meanly between 51 to 60 years old group, indicating that the exposure time may be an important epidemiological factor to neurogical manifestations and therefore, demand for diagnostics. The similar age group for NCC, based on CT diagnosis, was found in Baixada Fluminense since 1996 until 20025 , in Maringa since 1998 until 2004 and in Barbalha-Ceará since 2001 until 2004 ${ }^{14}$, however, in a previous study in Curitiba since 1995 to $1996^{6}$ the age group 31 to 40 years was more affected.

Cysts have been reported with 2-20 mm of diameter (7.5 mm on Brazilian national average) in the literature ${ }^{2}$. Three (3.29\%) hypodense processes were found and the size for two of them were reported, one with $8 \mathrm{~mm}$ and other with $10 \mathrm{~mm}$, indicating more recent stages of neurocysticercosis. Whereas in previous study, the hypodense 
processes (13 or 5.5\%) and both forms, hypodense and calcifications (3 or 1.3\%) were found in 236 cases of neurocysticercosis diagnosed patients in Curitiba ${ }^{6}$.

NCC cases were mostly from urban areas in epidemiological studies based on computed tomographies, such as a previous study in Curitiba $(78.40 \%)^{6}$, in Maringa $(93.75 \%)^{7}$, in Lages $(100 \%)^{8}$ and in Cianorte $(95 \%)^{13}$. Although most of suggestive neurocysticercosis patients were resident in Curitiba (78.02\%), is not possible to confirm when and where the infection occurred, since the disease has a chronic character and the calcification process completed over 5 years on average ${ }^{15}$.

In the present study, the computed tomography has been shown to be an efficient technique for the viable and calcified cyst diagnosis, moreover cysts localization, number and size may be considered. Although, other techniques could be considered when asymptomatic individuals are evaluated.

The lack of basic sanitation and sanitary education are factors that contribute to the cysticercosis transmission in urban zones ${ }^{5,13}$. Studies have shown the presence of viable Taenia solium ${ }^{16,17}$ and Taenia saginata ${ }^{17}$ eggs in sewage mud even after sewage treatment. In general, the sewage mud has been used for manuring in agriculture as way to a better destination ${ }^{18}$. However, it is noticed that the presence of pathogens must be a limiting factor considering the risk to the human and animal health ${ }^{16}$.

According to our results, chronic patients with inactive form of disease, adult and elder people, residents of Curitiba make up the pattern of diagnosed patients for NCC in this studied group. We notice only 03 cystic forms in patients and mostly inactive form of NCC suggesting past cases of infection probably due to improvement of public health status followed the development of urban area of Curitiba in the past decade.

The present study reinforces the necessity of adequate control programs for teniasis-cysticercosis and the importance of their notification to reducing new cases of diseases. Moreover, the adequate surveillance made by geographic mapping of affected areas associated to demographic, socioeconomic and environmental data may contribute to risk factors identification and the development of specific prevention strategies.

ACKNOWLEDGMENTS - We kindly thank the physicians and technicians of the Advanced Image Diagnostic Center - DAPI for providing valuable access to all necessary data.

\section{REFERENCES}

1. OPAS. Epidemiologia y control de la teníase/cisticercosis en América Latina. Versão 3.0. Washington: Organização Panamericana da Saúde, 1994.

2. Agapejev S. Clinical and epidemiological aspects of neurocysticercosis in Brazil: a critical approach. Arq Neuropsiquatr 2003;60:822-828.

3. Roberts T, Murrell KD, Marks S. Economic losses caused by food borne parasitic diseases. Parasit Today 1994;11:419-423.

4. Pal DK, Carpio A, Sander JWAS. Neurocysticercosis and epilepsy in developing countries. J Neurol Neurosurg Psychiatry 2000; 68:137-143.

5. Mendes EC, Silva SS, Fonseca EAL, Souza HRR, Carvalho RW. Human neurocysticercosis in Baixada Fluminense, Rio de Janeiro State, Brazil. Arq Neuropsiquiatr 2005; 63:1058-1062.

6. Narata AP, Arruda WO, Uemura E, et al. Neurocysticercosis: a CT-scan study in a series of neurological patients. Arq Neuropsiquiatr 1998;56:245-249.

7. Benedeti MR, Falavigna DLM, Falavigna-Guilherme AL, Araújo SM. Epidemiological and clinical profile of neurocysticercosis patients assisted by the Hospital Universitário Regional de Maringá, Paraná, Brazil. Arq Neuropsiquiatr 2007;65:124-129.

8. Pfuetzenreiter MR, Ávila-Pires FD. Manifestações clínicas de pacientes com diagnóstico de neurocisticercose por tomografia computadorizada. Arq Neuropsiquiatr 1999;57:653-658.

9. Instituto Brasileiro de Geografia e Estatística-IBGE. Estimativas da população para $1^{\circ}$ de julho de 2008. Avaiable at: http://www.ibge.gov.br/home/estatistica /populacao/estimativa2008/POP2008_DOU.pdf Acessed 08/07/2009.

10. Gusso R, Camargo NJ. Cenário da teníase e cisticercose no Paraná - 2002. Boletim epidemiológico, Saúde no Paraná, 2002;a.5, n.12.

11. Chagas MGL, D'Oliveira A Jr, Tavares-Neto J. Manifestações clínicas da neurocisticercose na região do semi-árido do nordeste brasileiro. Arq Neuropsiquiatr 2003;61:398-402.

12. Silva JEP, Diefenthäler AP, Palma JK. Frequency of suspected cases of neurocysticercosis detected by computed tomography in Santa Maria, RS, Brazil. Rev Inst Med Trop São Paulo 2000;42:57-58.

13. Segantim A, Melo SR. Prevalence of neurocysticercosis in the region of Cianorte - PR, from 1998 to 2003. Arq Ciên Saúde Unipar 2005; 9:161-165.

14. Silva MC, Cortez AA, Aquino-Cortez A, Valente M, Toniolli R. Porcine cysticercosis, taeniasis and human neurocysticercosis in municipal district of Barbalha, Ceará. Arq Bras Med Vet Zootec 2007;59:371-375.

15. Bittencourt PRM. Quando a cabeça dá problema: só os mutantes sobrevivem. Curitiba: Unidade de Neurologia Clínica, 2003: 92-96.

16. Paulino RC, Castro EA, Thomaz-Soccol V. Tratamento anaeróbio de esgoto e sua eficiência na redução da viabilidade dos ovos de helmintos. Rev Soc Bras Med Trop 2001;34:421-428.

17. Cutolo SA, Rocha AA. Uso de parasitas como indiciadores sanitários para análise da qualidade das águas de reuso. XXVII Congresso Interamericano de Engenharia Sanitária e Ambiental: Porto Alegre, 2000.

18. EMBRAPA. Boletim de Pesquisa e Desenvolvimento 20 - Lodo de esgoto na agricultura: estudo de caso. Jaguariuna: São Paulo, 2004. 